九州大学学術情報リポジトリ

Kyushu University Institutional Repository

\title{
The Large Scale Production of Cerrena unicolor Laccase on Waste Agricultural Based Media
}

Mazur, Iwona

Department of Biochemistry, Maria Curie-Skłodowska University

Rola, Beata

Department of Biochemistry, Maria Curie-Skłodowska University

Stolarczyk, Krzysztof

Faculty of Chemistry, University of Warsaw

Nazaruk, Ewa

Faculty of Chemistry, University of Warsaw

他

https://doi.org/10.5109/1526341

出版情報：九州大学大学院農学研究院紀要. 60 (2)，pp. 297-302，2015-09-18. Faculty of Agriculture, Kyushu University

バージョン :

権利関係 : 


\title{
The Large Scale Production of Cerrena unicolor Laccase on Waste Agricultural Based Media
}

\section{Iwona MAZUR ${ }^{1}$, Beata ROLA ${ }^{1}$, Krzysztof STOLARCZYK ${ }^{2}$, Ewa NAZARUK ${ }^{2}$, Renata BILEWICZ², Jerzy ROGALSKI ${ }^{1 *}$ and Shoji OHGA*}

\author{
Laboratory of Forest Resources Management, Division of Forest Environmental Science, \\ Department of Agro-environmental Sciences, Faculty of Agriculture, \\ Kyushu University, Sasaguri, Fukuoka 811-2415, Japan \\ (Received April 14, 2015 and accepted May 19, 2015)
}

\begin{abstract}
The effect of different agriculture waste polysaccharides as an only carbon source in culture medium of wood-degrading basidiomycete Cerrena unicolor C-139 were investigated. The maximal growth and laccase synthesis in shaken flask was observed in mineral salts broth containing potato starch as the carbon source and asparagine as the nitrogen source (11,000 nkat/L). When an optimized medium was stimulated by addition of $10 \mu \mathrm{M} \mathrm{Cu}^{2+}$ to the culture medium on days 3-5 the maximal activity 24,000 nkt/L was obtained. Next the influence of the stabilization of the medium pH after 48-h incubation on laccase activity in fermentor cultures had to be estimated. The obtained data show that use of an automatic $\mathrm{pH}$ control set at $\mathrm{pH} 5.0$ increased laccase productivity significantly (by 12 times) as compared to that obtained in the fermentor culture with a non-stabilized pH-value. Under the new conditions, the highest enzyme activity of 290,000 nkat/L was reached after 13-day incubation.
\end{abstract}

Key words: Cerrena unicolor, laccase, culture factors, wood degrading, fermentor

\section{INTRODUCTION}

The lignin is one of the most abundant polymer in the nature. The best characterized and most extensively studied lignin degrading organisms are the white rot fungi (Leonowicz et al., 2001). The ligninolytic enzymes of white rot fungi known so far can be divided into three groups. The first one attack directly the wood constituents; this group includes enzymes acting on carbohydrate components (cellulose, hemicellulose) and lignin. The second of three above mentioned groups includes enzymes cooperates with the first one but they neither attack wood nor contribute to it. The third, very important group so called feedback type enzymes play a key role in combining the metabolic chains during biodeterioration of the wood polymer (Leonowicz et al., 1999).

Laccases (EC 1.10.3.2, p-diphenol: oxygen oxidoreductase) are multi copper-containing oxidases, catalyzing the oxidation of ortho- and para-diphenols, polyphenols, arylamines, aminophenols and some inorganic ions, while simultaneously reducing molecular dioxygen to water (Solomon et al., 1996; Shleev et al., 2005; Viswanath et al., 2008).

Laccases are classified into two groups in accordance with their source: plant and fungal (Mayer and Staples, 2002). However, diphenol oxidases have also been identified in bacteria (Givuadan et al., 1993) and insects (Barrett, 1991). In the fungi belongs to the most effective producers of this biocatalyser were discovered three forms of laccases so called blue (Gochev and Krastanov,

Department of Biochemistry, Maria Curie-Skłodowska University, Akademicka 19 Str., 20-031 Lublin, Poland

Faculty of Chemistry, University of Warsaw, Pasteura 1 Str., 02-093 Warsaw, Poland

* Corresponding Authors (E-mail: ohga@forest.kyushu@u.ac.jp, rogal@hermes.umcs.lublin.pl)
2007), yellow (Leontievsky et al., 1999) and white ones (Palmieri et al., 1997). Because of their broad substrate specificity, native or immobilized laccases can be potentially used in textile dye bleaching, pulp delignification, effluent detoxification, washing of powder components, removal of phenolics from effluents, must, wine and fruit juices, transformations of steroids and antibiotics as well as in biosensors (Duran et al., 2002; Mayer and Staples, 2002; Minusi et al., 2002; Widsten and Kandelbauer, 2008; Giardina et al., 2010). The production of fungal laccases is associated with secondary metabolism, the main drawback of which is the limited yield of the enzyme obtained under growth-limiting conditions (Moreira et al., 2000). To utilize laccases more efficiently for diverse bioprocesses, large amounts of enzyme are required (Gianfreda et al., 1999). At present, research and application are sometimes hindered by the rather low yields of the enzyme formed by used producers as well as by the difficulties in efficiently overexpressing laccases in active form heterologously (Jönsson et al., 1997). The problem of increasing the yield of ligninolytic enzymes in cultures of the fungal producers is a subject of constant interest (Kantelinen et al., 1989), since the wild strains give extremely low concentrations of these biocatalysts when non-optimized media and culture conditions are used (Tien and Kirk, 1989).

Recently, C. unicolor was determined as a new fungal source of extracellular laccase, excreting the enzyme under non-induced conditions with a rate similar to the best laccase producers. Several attempts to increase its production as well a scale up process were undertaken, including optimization of the mediums composition and the physical parameters of the culture (Leonowicz et al., 1997; Janusz et al., 2007; Rogalski and Janusz, 2010; Rola et al., 2013). Reducing the costs of laccase production by optimising the fermentation process in finding effi- 
cient and cheap carbon source in the media is the basic research for the industrial applications (Fenice et al., 2003; Kachlishvilli et al., 2014).

For these reasons the present study was conducted in order to find the best cultural conditions for the overproduction of laccase by $C$. unicolor in shaken flasks and aerated fermentor cultures, and to search for the most effective inducers of enzyme synthesis in the media containing the agricultural waste substances. The information provided by this study will add to the scarce information currently available on the production of laccase by $C$. unicolor.

\section{MATERIALS AND METHODS}

\section{Organism}

Cerrena unicolor C-139 was obtained from the culture collection of the Regensburg University and deposited in the fungal collection at the Department of Biochemistry (Maria Curie-Skłodowska University, Poland) under the strain number 139. Stock cultures of the fungus were stored at $4^{\circ} \mathrm{C}$ on malt agar slants. For inoculations, pieces of mycelium overgrowing agar were grown using Lindeberg and Holm (1952) medium (pH 5.5 ) in stationary conical flasks for 7 days at $28^{\circ} \mathrm{C}$. The mycelial mats were subsequently collected, broken in a Waring blender (three times for $15 \mathrm{~s}$ at 10,000 rpm), and homogenates were used as inoculum in shaking and aerated bioreactor cultures.

\section{Culture Conditions}

For the development of a laboratory scale inoculum the bioreactor-scale cultivations were performed at $28^{\circ} \mathrm{C}$ in a $3.5 \mathrm{~L}$ glass fermentor (BioFlo III, New Brunswick Scientific, Edison, NY, USA) containing 2.0 L of the optimized Lindeberg-Holm medium (Rola et al., 2013). The fermentor equipped with $\mathrm{pH}$, temperature and $\mathrm{CO}_{2}$ sensors was sterilized $\left(121^{\circ} \mathrm{C}, 40 \mathrm{~min}\right)$ and seeded with mycelial suspension (10\% of total volume). The fungal culture was run for 14 days at the aeration rate of $1 \mathrm{~L}$ air min $^{-1}$ with air and stirrer speed of $150 \mathrm{rpm}$. Antifoam B emulsion (Sigma-Aldrich Fine Chemicals, St. Louis, MO, USA) was used periodically to break the foam and the $\mathrm{pH}$ was not regulated. The laboratory scale fermentation was done in the $7 \mathrm{~L}$ fermentor BioFlow type 115 (New Brunswick Scientific, Edison, NY, USA) The fermentor vessel contained $4 \mathrm{~L}$ of the optimized Lindeberg-Holm medium and sterilized at $121^{\circ} \mathrm{C}$ by $45 \mathrm{~min}$. For the inoculation the mycelial suspension from BioFlo III fermentor $(0.5 \mathrm{~L})$ was added into the vessel via sterilized port. The fungal culture was run for 14 days at the aeration rate of $2 \mathrm{~L}$ air $\mathrm{min}^{-1}, 28^{\circ} \mathrm{C}$ and stirrer speed of $200 \mathrm{rpm}$. Antifoam B emulsion, used to break the foam, as well the samples of the medium was taken via sterilized ports. The fermentor was equipped with $\mathrm{pH}-$, temperature and dissolved $\mathrm{O}_{2}$ sensors.

\section{The effect of different carbon sources on laccase synthesis}

To study the different waste carbon sources on lac- case production, C. unicolor was grown in $50 \mathrm{ml}$ widemouth Erlenmeyer flasks with $15 \mathrm{ml}$ optimized earlier Lindenberg Holm medium (Janusz et al., 2007) containing $10 \mathrm{~g} / \mathrm{l}$ : Avicell cellulose (Sigma, St.Louis, USA), oat and barley brans (SANTE sp.j.; Warsov, Poland), wheat bran - starch free (Helsingin Mylly Oy, Helsinki), potato starch (POCH, Gliwice Poland), wheat flour (Lubella sp. Z o.o., Lublin, Poland), corn flour (BioPlanet sp. z o.o., Leszno, Poland), oat flour (Symbio s.a., Warsov, Poland), barley flour (Melvit s.a., Warsov, Poland), rice flour (BEZGLUTEN s.a., Koniusza, Poland) $10 \mathrm{kDa}$ dextrane (Polfa, Kutno, Poland), cane molasse (PRO NATURA, Walcz, Poland), sugar beet molasse (Horizon Natuurvoerding BV, IJsselstein, Holland), or whey (Mogador s.r.o., Otrkovice, Czech Republic) instead glucose. The flasks were incubated on orbital rotary shaker Multitron (Inforce HT, Bottmingen/Basel, Switzerland) at $28^{\circ} \mathrm{C}$ and $160 \mathrm{rev} / \mathrm{min}$ for a period of 14 days.

\section{The biomass determination}

In order to determine the dynamics of mycelium growth, the after culture fluids were centrifuged at $10,000 \mathrm{x} g$ by $10 \mathrm{~min}$ and washed two times by MilliQ water (Millipore, Bedford, USA). Next the mycelia were suspended in $15 \mathrm{ml}$ MilliQ water, disrupted three times during $60 \mathrm{~s}$ in an ultrasonic disintegrator (Sonics Vibracell, Newtown, USA) and the homogenates were centrifuged at 10,000 x g for $10 \mathrm{~min}$ (Okunev et al., 1981). In cell-less extracts the content of protein was determined (Bradford, 1976), which was used as a rough index of mycelium growth. The results presented are the mean of mycelium growth obtained in two separate cultivations.

\section{Enzyme Purification}

The after culture liquid was centrifuged at 10,000 x g on CEPA LE Benchtop centrifuge (New Brunswick Scientific, Edison, NY, USA) with the flow rate $15 \mathrm{~L} / \mathrm{h}$. The supernatant was next concentrated about 25 times on the ultrafiltration system Prep/Scale TFF-6 $\left(0.54 \mathrm{~m}^{2}\right)$ cartridges (Millipore, Bedford, USA) with PT polyethersulfone membrane (10 kDa cut off), desalted on Sephadex G-25 column, distributed into lyophilisation vials and lyophilised in Labconco FreeZone 12 (Labconco, Kansas, MO, USA).

\section{Laccase Activity and Protein Measurement}

Laccase activity in culture supernatant was measured spectrophotometrically at $525 \mathrm{~nm}$ in Shimadzu UV-Vis 160A spectrophotometer (Tokyo, Japan) or at BioTek ELx800 Absorbance Microplate Reader (Winooski, USA) controlled by KC-Junior (v. 1.41.8) software using syringaldazine as a substrate (Leonowicz and Grzywnowicz 1981). One nano katal (nkat) of laccase activity was defined as the amount of enzyme catalyzing the production of one nano mol of coloured product (quinone, $\varepsilon^{\mathrm{M}}=$ $65,000 \mathrm{M}^{-1} \mathrm{~cm}^{-1}$ ) per second at $25^{\circ} \mathrm{C}$ and $\mathrm{pH} 5.5$, and expressed as nano katals per litre of culture (nkat/L). The protein concentration was determined using the Bio-Rad Protein Assay Reagent using bovine serum albumin (BSA) as standard (Bradford, 1974) or fluorometri- 
caly on Qubit 2 with Qubit Protein Assay Kit (Ahnert et al., 2007).

\section{RESULTS AND DISCUSSION}

The white rot fungus $C$. unicolor belong to the one of the most effective extracellular laccase producers in not inductive conditions (Leonowicz et al., 2001, Janusz et al., 2007; Rola et al., 2013). This fungus can use different carbon sources as monosaccharides (glucose, fructose, galactose) as well disaccharides (maltose, fructose, cellobiose, lactose) in cultivation processes. It can suggest the possibility of them the production of $\beta$-fructofuranosidase, $\beta$-galactosidase, $\beta$-glucosidase and $\alpha$-glucosidase the enzymes acting on $\alpha$ - and $\beta$ glicosidic bonds (Rola et al., 2013). The starting point of these studies was the selection of different carbon sources as the $\alpha$-and $\beta$-glucans be located in different waste agriculture materials as well as molasses instead glucose in Lindenberg-Holm medium for effective production of extracellular laccase by $C$. unicolor. Titres of laccase were measured for 14 days in shaken flask cultures. The results (Table 1 ) indicated that the enzyme activity reached its maximum (over 11,000 nkat/l on day 10) in the medium containing potato starch. The high laccase activities according to the control condition (medium with glucose) were also observed for rye bran $(10,800$ nkat/l; 10 day), outs bran (7,060 nkat/l; 7 day) and cane and sugar beet molasses $(6,800$ nkat/l at 6 and 10 day respectively). The best carbon source (potato starch) concentration in the medium was next optimized. The concentration of carbon (added as potato starch) varied

Table 1. Laccase synthesis during $C$. unicolor growth on different $1 \%$ carbon sources

\begin{tabular}{|c|c|c|c|}
\hline Carbon source & $\begin{array}{c}\text { *HLA } \\
\text { [nkat/l] }\end{array}$ & $\begin{array}{c}\text { Time of } \\
\text { HLA } \\
\text { [day] }\end{array}$ & $\begin{array}{c}\text { Increase } \\
\text { according to } \\
\text { glucose } \\
\text { [fold] }\end{array}$ \\
\hline Maize flour & 8560 & 14 & 1.57 \\
\hline Rice flour & 2410 & 14 & 0.44 \\
\hline Rye flour & 5660 & 14 & 1.03 \\
\hline Out flour & 4280 & 14 & 0.78 \\
\hline Wheat flour & 5400 & 7 & 0.98 \\
\hline Potato starch & 11040 & 10 & 2.00 \\
\hline Oats bran & 7060 & 7 & 1.28 \\
\hline Rye bran & 10800 & 10 & 1.96 \\
\hline Wheat bran & 1000 & 12 & 0.18 \\
\hline Cellulose & 1290 & 10 & 0.23 \\
\hline Dextran & 2060 & 11 & 0.36 \\
\hline Cane molasses & 6800 & 6 & 1.23 \\
\hline Sugar beet molasses & 6800 & 10 & 1.23 \\
\hline Whey & 3500 & 8 & 0.64 \\
\hline Wheat straw & 2306 & 11 & 0.42 \\
\hline
\end{tabular}

*HLA - highest laccase activity from 1 to $50 \mathrm{~g} / \mathrm{l}$ while that of nitrogen (added as L-asparagine) was $1.5 \mathrm{~g} / \mathrm{L}$ as in (Janusz et al., 2007; Rola et al., 2013). The results indicated that the enzyme activity reached its maximum (over 25,000 nkat/l on day 14) in cultures containing $50 \mathrm{~g} / \mathrm{L}$ potato starch as a carbon source (Fig. 1). The lowest starch concentration in the medium affect lowest laccase activities but obtained much faster.

In the next stage of experiments optimization of the laccase production of $C$. unicolor growing in the medium with potato starch (5\%) as a carbon source in 3.5 L fermentor at $200 \mathrm{rpm}$ was done. For the inoculation of a $3.5 \mathrm{~L}$ fermentor the obtained earlier mycelium from early (5d) expotential growth phase, were used according to (Rola et al., 2013). The highest laccase activity was observed in the 6th day of cultivation where the $\mathrm{pH}$ drop down to the about 4.0 level (Fig. 2A). Parallel to the control conditions the cultivation with the sequential addition of $10 \mu \mathrm{M}$ cupric ions doses from 3 to 5 day of growth was made (Fig. 2B). Obtained there activities were 1.5 times higher as in control fermentor and 2.2 times higher as in shaking conditions.

Cupric ions had been reported as the strong stimulants of laccase activity by Giardina et al. (1999) and Galhaup et al. (2002), in whose experiments up to 50 times higher levels of the enzyme were obtained in induced, compared to non-induced, cultures. The optimal copper dose for the enzyme production by $C$. unicolor C-139 in shaken flask as well fermentor cultures was found to be $10 \mu \mathrm{M}$ (Janusz et al., 2007; Rola et al., 2013). The optimal $\mathrm{Cu}^{2+}$ dose was significantly lower than that (2.0 mM, added after 4 days of incubation) reported by Galhaup and Haltrich (2001) for submerged cultures of $T$. pubescens, but was still within the range of 2 to $600 \mu \mathrm{M}$ used in typical cultivation media for the production of laccase both in wild-type and recombinant strains of different basidiomycete fungi (Palmieri et al., 2000; Chen et al., 2003). It had also been reported (Palmieri et al., 2000) that the induction of laccase in $P$. ostreatus occurred when the fungus was cultivated in a nutrientrich medium supplemented with $150 \mu \mathrm{M} \mathrm{CuSO}{ }_{4}$ at the time of inoculation.

It is significant that in all shaken flasks and aerated fermentor cultures carried out without pH-regulation (self-control of medium $\mathrm{pH}$ by the fungus took place) in

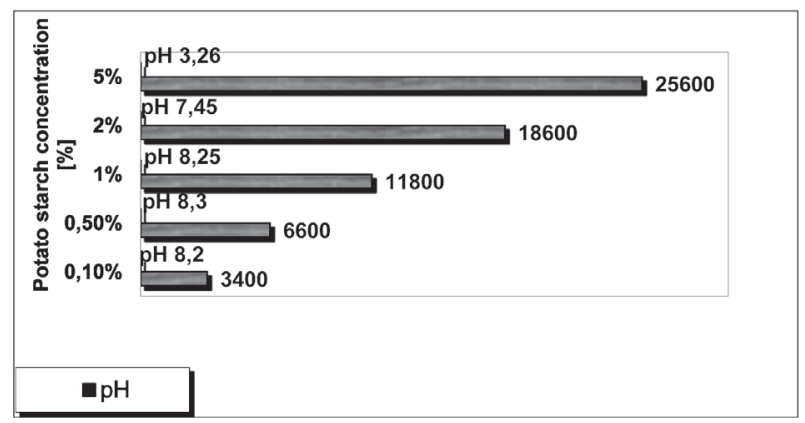

Fig. 1. The relationship between extracellular laccase synthesis and potato starch concentration in the $C$. unicolor cultivation media.

*HLA - highest laccase activity 
A
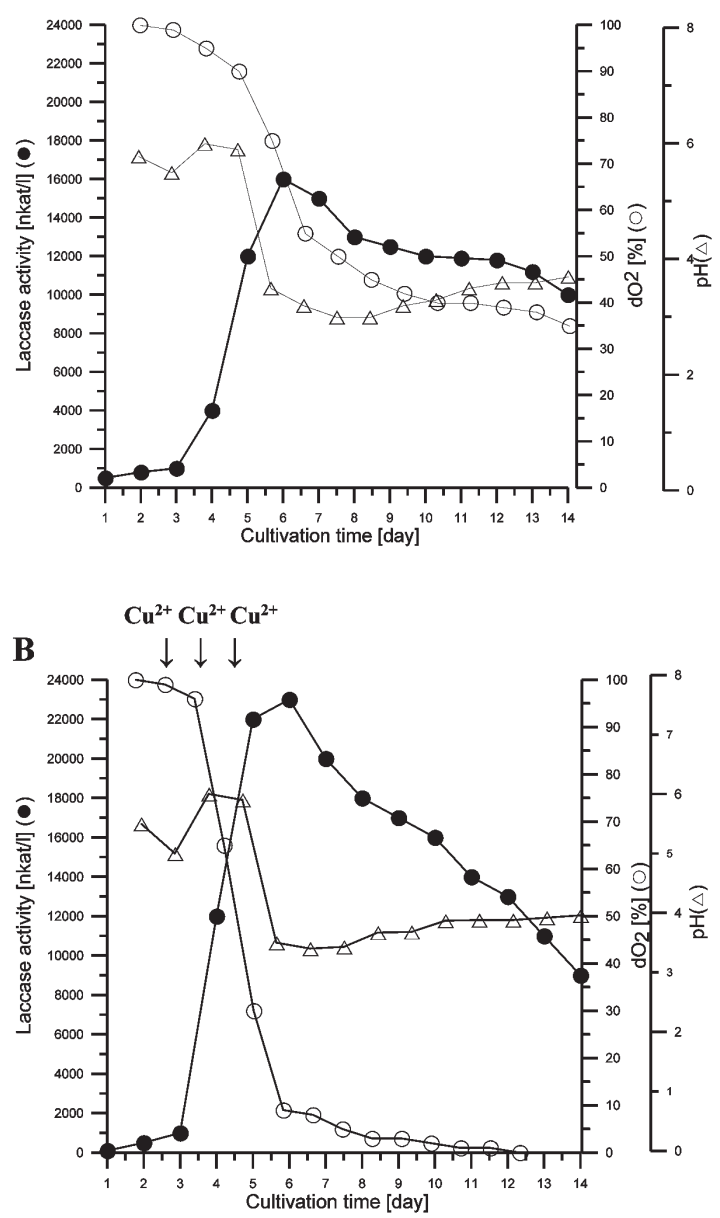

Fig. 2. The course of a typical C. unicolor laboratory-scale fermentation in the medium without $\mathrm{Cu}^{2+}$ complementation (A) and with $\mathrm{Cu}^{2+}$ complementation (B).

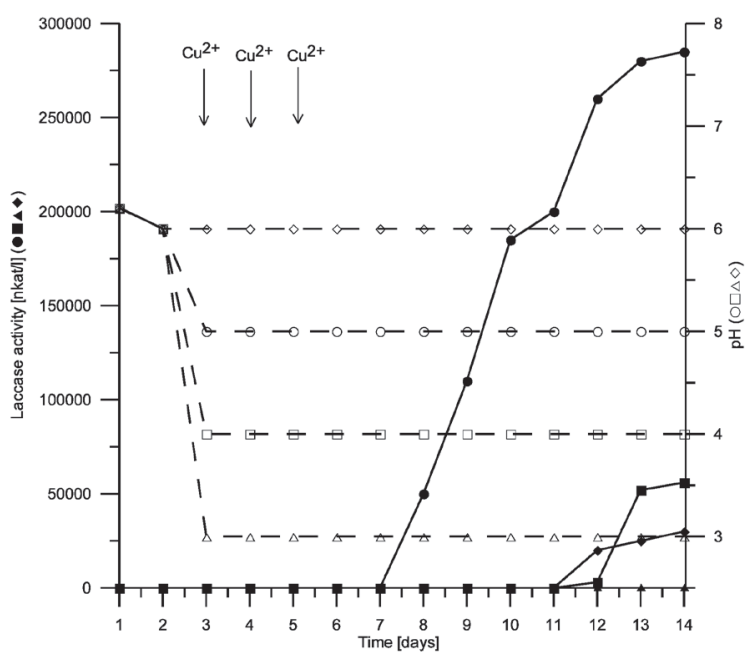

Fig. 3. Effect of stabilisation of medium $\mathrm{pH}$ on laccase production by C. unicolor in fermenter cultures on LindenbergHolm medium. The $\mathrm{pH}$ was automatically maintained at a value of $3.0(\triangle ; \mathbf{\Delta}), 4.0(\square ; \mathbf{\square}), 5.0(\bigcirc ; \mathbf{O})$ and 6.0 $(\diamond ; \diamond)$ after $48 \mathrm{~h}$ incubation (marked in the chart as horizontal dash lines). Cupric ions $(10 \mu \mathrm{M})$ were added to the medium after 3,4 and 5 days of cultivation (arrows show addition of $\mathrm{Cu}^{2+}$ into the medium). Cultures conditions: stirrer speed, $200 \mathrm{rev} / \mathrm{min}$; aeration rate, $2 \mathrm{~L} / \mathrm{min}$. Open symbols: pH; filled symbols: laccase activities. media containing mono and disaccharides as the only carbon sources, the fungus alkalized the medium during cultivation, resulting in a $\mathrm{pH}$ rise from 5.5 to about 8.0 (Janusz et al., 2007; Rola et al., 2013). In the case where potato starch was used as the only carbon source it was observed opposite tendency. Grow up of $C$. unicolor laccase activities in the medium were connected with decrease of medium pH to about 4.0 (Fig. 2). Given this, the influence of the stabilization of the medium $\mathrm{pH}$ after 48-h incubation on laccase activity in fermentor cultures had to be estimated (Fig. 3) The obtained data show that use of an automatic pH control set at pH 5.0 increased laccase productivity significantly (by 12 times) as compared to that obtained in the fermentor culture with a non-stabilized $\mathrm{pH}$-value. Under the new conditions, the highest enzyme activity of 290,000 nkat/L was reached after 13-day incubation. The maintenance of medium $\mathrm{pH}$ on the level of 3.0 was completely unfavorable (no laccase activity was obtained) and that of 4.0 gave a smaller effect $(65,000 \mathrm{nkat} / \mathrm{L}$ of enzyme was produced) as well as at $\mathrm{pH} 6.0$ than the laccase activity reached 40,000 nkat/L. These different effect of $\mathrm{pH}$ stabilization on extracellular laccase activity can be resulted by differential responses to abiotic stress. Moreira et al. (2000) using a fermentor with $\mathrm{pH}$ fixed at 5.5 during the whole period of incubation obtained the highest effective production of this enzyme in Bjerkandera sp. Also, Núske et al. (2002) using a cyclic batch system for MnP production (by Nematoloma frowardii and Clitocybula dusenii) as well as Koroleva et al. (2002) in the Coriolus hirsutus cultivation obtained the similar results.

Next the right moment of $\mathrm{pH}$ stabilization was deter-

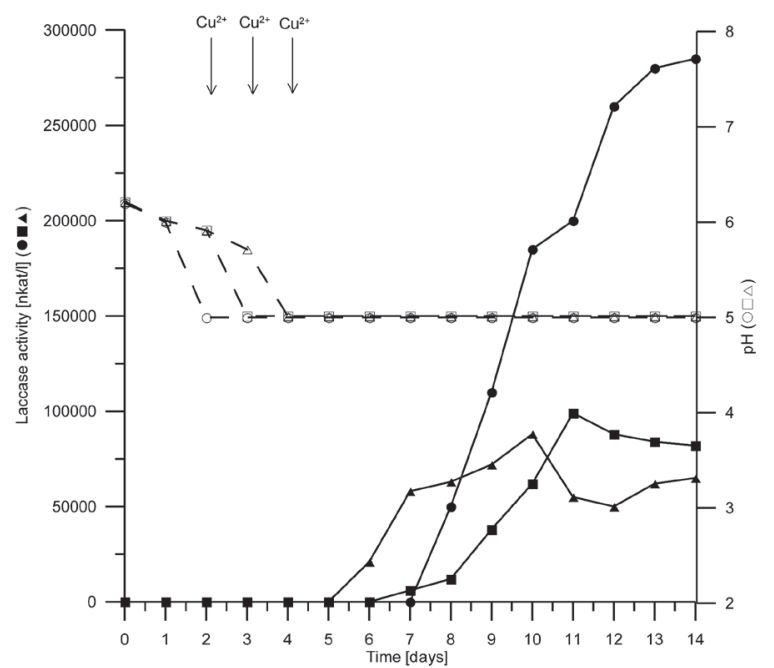

Fig. 4. Time course of laccase production $(\mathbf{O}, \boldsymbol{\square}, \boldsymbol{\Delta})$ during fermentor cultures of $C$. unicolor in the LindebergHolm medium. The medium $\mathrm{pH}$ was automatically maintained at a value of 5.0 (marked in the chart as a solid line) after $48(\bigcirc), 72(\square)$ and $96 \mathrm{~h}(\triangle)$ of incubation (dashed lines show the days on which the medium $\mathrm{pH}$ was adjusted to the adequate value). Cupric ions $(10 \mu \mathrm{M})$ were added to the medium after $3-5$ days of cultivation (arrows show addition of $\mathrm{Cu}^{2+}$ into the medium). Culture conditions: stirrer speed, $200 \mathrm{rev} / \mathrm{min}$; aeration rate $2 \mathrm{~L} / \mathrm{min}$. 
mined (Fig. 4). As discussed above, the best laccase productivity (290,000 nkat/L) was recorded when the maintenance of medium $\mathrm{pH}$ on the level of 5.0 was performed on the second day of cultivation. The obtained laccase activity was 10 times higher that when $C$. unicolor had been grown in the original non optimised conditions (Rogalski et al., 1999). The maximal laccase activities are connected with reaching the stationary growing phase. The after culture fluid showing the highest laccase activities were taken out from the fermentor and centrifuged for removing the mycelium. The supernatants containing laccase were next concentrated by ultrafiltaration, purified by ion-exchange chromatography on DEAE-Sepharose (fast flow) and liophylized to obtain the enzyme preparation.

\section{CONCLUSION}

Summarizing, the data presented here imply that the tested $C$. unicolor strain can synthesis the high active preparation in submerged and fermentor cultures containing potato starch as only carbon source. The study also shows that an appropriate combination of culture conditions (i.e. a C- and N-sufficient medium) combined with supplementation with an adequate dose of $\mathrm{Cu}^{2+}$ ions supply on a yield of laccase production. In fermentor cultures, the maintance of medium $\mathrm{pH}$ at the optimized level increase laccase productivity 12 times.

\section{ACKNOWLEDGEMENTS}

This work was supported by the research program "Tailored Lipidic Mesophases as Novel Functional Nanomaterials in Bioenergetics and Biosensing" under the framework of Polish-Swiss Research Programme No. PSPB-079/2010, The National Center for Research and Development (NCBiR), grant NR05-0017-10/2010 (PBR11) and the research program BS/UMCS.

\section{REFERENCES}

Barrett F. M. 1991 Phenoloxidases and the integument. In "Physiology of the insect epidermis", ed. by K. Binnington and A. Retnakaren, East Melbourne, Vic., Australia, CSIRO Publ., pp. 195-212

Bradford M. M. 1976 A rapid and sensitive method for the quantitation of microgram quantities of protein utilizing the principle of protein-dye binding, Anal. Biochem., 72: 248-254

Duran N., M. A. Rosa, A. D. Annibale and L. Gianfreda 2002 Applications of laccases and tyrosinases (phenoloxidases) immobilized on different supports: a review, Enzyme Microb. Technol., 31: 907-931

Fenice M., G. G. Sermanni, F. Federici and A. D'Annibale 2003 Submarged and solid-state production of laccase and Mn-peroxidase by Panus tigrinus on olive mill wastewaterbased media. J. Biotechnol., 100: 77-85

Gianfreda L., F. Xu and J.-M. Bollag 1999 Laccases: a useful group of oxidoreductive enzymes. Biorem. J., 3: 1-25

Giardina P., V. Faraco, C. Pezzella, A. Piscitelli, S. Vanhulle and G. Sannia 2010 Laccase: a never-ending story. Cell.Mol. Life Sci., 67: 369-385

Givaudan A., A. Effosse, D. Faure, P. Portier, M.-L. Bouillant and R. Bally 1993 Polyphenol oxidase in Azospirillum lipoferum isolated from rice rhizosphere: Evidence for laccase activity in non-motile strains of Azospirillum lipoferum. FEMS Microbiol. Lett., 108: 205-210

Janusz G., J. Rogalski and J. Szczodrak 2007 Increased production of laccase by Cerrena unicolor in submerged liquid cultures. World J. Microb. Biotechnol., 23: 1459-1464

Jönsson L. J., M. Saloheimo and M. Penttilä 1997 Laccase from the white-rot fungus Trametes versicolor: cDNA cloning of lcc1 and expression in Pichia pastoris. Curr. Genet., 32: 425-430

Kashlishvilli E., E. Metieveli and V. Ekisashvilli 2014 Modulation of Cerrena unicolor laccase and manganese peroxidase production. Springer Plus, 3: 463 (doi:10.1186/2193-1801-3463)

Kantelinen A., A. Hattaka and L. Viikari 1989 Production of lignin peroxidase and laccase by Phlebia radiate. Appl. Microbiol. Biotechnol., 31: 234-239

Koroleva O. V., E. V. Stepanova, V. P. Gavrilova, N. S. Yakovleva, E. O. Landesman, I. S. Yavmetdinov and A. I. Yaropolov 2002 Laccase and Mn-peroxidase production by Coriolus hirsutus strain 075 in a jar fermentor. J. Biosci. Bioeng., 93: 449-455

Leonowicz A., L. Gianfreda, J. Rogalski, M. Jaszek, J. Luterek, M. Wojtaś-Wasilewska, E. Malarczyk, A. Dawidowicz, M. FinkBoots, G. Ginalska, M. Staszczak and N-S. Cho 1997 Appearance of laccase in wood-rotting fungi and its inducibility. J. Kor. Wood Sc., Technol. 25: 29-36

Leonowicz A., N.-S. Cho, J. Luterek, A. Wilkolazka, M. WojtasWasilewska, A. Matuszewska, M. Hofrichter, D. Wesenberg and J. Rogalski 2001 Fungal laccase: properties and activity on lignin. J. Basic. Microbiol., 41: 185-227

Leonowicz A., A. Matuszewska, J. Luterek, D. Ziegenhagen, M. Wojtas-Wasilewska, M. Hofrichter, J. Rogalski and N.-S. Cho 1999 White-rot fungi as lignin degraders. Proc. Internat'l Conf. For. Sci., Chungbuk Nat. Univ., Chengju, Korea, $\mathbf{2 7}$ 175-193

Leontievsky A., N. Myasedova, B. Baskunov, N. Pozdnyakova, T. Vares, N. Kalkkinen, A. Hatakka and L. Golovieva 1999 Reaction of blue and yellow fungal laccases with lignin model compound. Biochemistry, 64: 1150-1156

Lindeberg G. and G. Holm 1952 Occurrence of tyrosinase and laccase in fruit bodies and mycelia of some Hymenomycetes Physiol. Plant, 5: 100-114

Mayer, A. M. and Staples,R. C. (2002) Laccase: new function for an old enzyme. Phytochemistry, 60: 551-565

Minussi R. C., G. M. Pastore and N. Duran 2002 Potential applications of laccase in the food industry. Tr. Food Sci. Technol., 13: $205-216$

Moreira M. T., A. Torrado, G. Feijoo and J. M. Lema 2000 Manganese peroxidase production by Bjerkandera sp. BOS55. 2. Operation in stirrer tank reactors. Bioprocess Eng., 23 : $657-661$

Nüske J., K. Scheibner, U. Dornberger, R. Ullrich and M. Hofrichter 2002 Large scale production of manganese-peroxidase using agaric white-rot fungi. Enzyme Microbial Technol., 30: 556561

Okunev O. N., T. I. Bilai, E. G. Musich and E. L. Golovlev 1981 Obrazovanie tsellylulaz plesnevymi gribami pri roste na tsellyulozosoderzhashchikh substratakh. Prikl. Biokhim. Mikrobiol., 17: 408-413

Palmieri G., P. Giardina, C. Bianco, A. Scaloni, A. Capasso and G. Sannia 1997 A novel white laccase from Pleurotus ostreatus. J. Biol. Chem., 272: 31301-31307

Rogalski J. and G. Janusz 2010 Purification of extracellular laccase from Cerrena unicolor. Prep. Bioch. Biotechnol., 40: 242255

Rola B., M. Karaskiewicz, D. Majdecka, I. Mazur, R. Bilewicz, J. Rogalski and S. Ohga 2013 Scale up of Cerrena unicolor laccase production. J. Fac. Agr., Kyushu Univ., 58: 231-238

Shleev S., J. Tkac, A. Christenson, T. Ruzgas, A.I. Yaropolov, J. W. Whittaker and L. Gorton 2005 Direct electron transfer between copper-containing proteins and electrodes. Biosens. Bioelectron., 20: 2517-2554

Solomon E. I., U. M. Sundaram and T. E. Machonkin 1996 
Multicopper oxidases and oxygenases. Chem. Rev., 96: 25632605

Tien M. and T. K. Kirk 1984 Lignin-degrading enzyme from Phanerochaete chrysosporium: Purification, characterization, and catalytic properties of a unique $\mathrm{H}_{2} \mathrm{O}_{2}$-requiring oxygenase. Proc. Natl. A cad. Sci. USA, 81: 2280-2284

Viswanath B., M.S. Chandra, H. Pallavi and B. Rajasekhar-Reddy
2008 Screening and assessment of laccase producing fungi isolated from different environmental samples. Afr. J. Biotechnol., 7: 1129-1133

Widstein P. and A. Kandelbauer 2008 Laccase applications in the forest products industry: A review. Enzyme Microbiol. Technol., 42: 293-307 